\title{
ANALISA PENGARUH TEORI GONE FRAUD TERHADAP ACADEMIC FRAUD DI UNIVERSITAS MUHAMMADIYAH SUKABUMI
}

\author{
Ismet Ismatullah \\ Program Studi Akuntans, Fakultas Ekonomi \\ Universitas Muhammaadiyah Sukabumi \\ ismet.ismatullah@ymail.com1 \\ Elan Eriswanto \\ Program Studi Akuntansi, Fakultas Ekonomi \\ Universitas Muhammaadiyah Sukabumi \\ rland_smi@yahoo.co.id
}

\begin{abstract}
This study intends to find out the cause of how big the effectiveness and role GONE theory against academic fraud. In this study, involving students from Sukabumi Muhammadiyah University from all exiting Program. Research conducted included in quantitative research and processed using the statistical program. The data used in this study uses primary data from questionnaires distributed to students and than do processed and analized in order to obtain results about the object and can be deduced.The results showed that of the four hypotheses proposed are two hypotheses were accepted and two rejected. Greed and Need which are internal factors inherent in a person are the root causes of academic fraud while opportunity and exposure factors which are outside factors do not have a role in the academic fraud.
\end{abstract}

Keywords: Fraud, Academic Fraud, and GONE Theory

\section{Pendahuluan}

Tahun 2014, Transparency International, melalui penerbitan Coruption Perception Index (CPI) menobatkan Indonesia sebagai penyandang peringkat 107 dari 175 negara dalam urusan transparansi dan bebas korupsi. Tentunya peringkat tersebut mempertegas bahwa penyakit korupsi di Indonesia semakin akut. Naasnya perilaku-perilaku korupsi tidak hanya bersarang di kalangan teras saja yang senantiasa menjadi sorotan publik. Ada satu hal yang tentunya perlu menjadi bahan refleksi dan sorotan pula, yakni praktik menyontek dikalangan pelajar/ mahasiswa. Ketua KPK Abraham Samad dalam berbagai kesempatan mengatakan bahwa kecurangan akademik walaupun hanya sekadar mencontek masuk dalam kategori korupsi, yaitu korupsi intelektual. Mengerikan sekali menyadari bahwa generasi mudapun bisa menjadi pelaku korupsi. Bisa jadi nantinya mereka akan menjadi pelaku korupsi yang sebenarnya.

Menurut Lozier dalam student perceptions of academic dishonesty scenarios, menyimpulkan hingga $70 \%$ pelajar berlaku curang paling sedikitnya satu kali ketika menempuh pendidikan di universitas, dan $25 \%$ berlaku curang lebih dari satu kali. Republika 07 Juni 2011 menyebutkan bahwa telah terjadi kasus mencontek massal di Surabaya yang melibatkan guru dan Kepala Sekolah. Selain terjadi di Indonesia, kasus serupa juga terjadi di Universitas Harvard yang melibatkan 125 mahasiswa pada bulan Agustus 2012.

Kecurangan akademik (academic fraud) bukanlah hal baru di dunia pendidikan khususnya di Indonesia. Misalnya mencontek saat ujian, baik melihat buku, membawa catatan kecil, mencari jawaban dengan browsing lewat handphone ataupun meng-copy tugas hasil pekerjaan temannya. Dengan sadar ataupun tidak setiap mahasiswa pasti telah melakukan perbuatan yang mengarah pada kecurangan akademik. Apabila hal tersebut tidak ditindaklanjuti, dikhawatirkan akan membangun persepsi bahwa kecurangan merupakan sesuatu yang wajar dan bersifat umum dan ini akan berimplikasi pada kecurangan professional.

Penelitian yang dilakukan oleh Sierra dan Hyman (2008) menyebutkan bahwa pelajar yang selalu melakukan kecurangan akan cenderung terlibat dalam situasi serupa ketika menemui kesempatan di dunia 
kerja nantinya.Dalam Buku Panduan Fraud Auditing yang dikeluarkan oleh BPKP (2008), terdapat empat factor penyebab seseorang melakukan korupsi, yaitu Greed, Opportunity, Need dan Exposure atau lebih dikenal dengan nama Teori GONE yang dikenalkan oleh Jack Boulogne dalam buku Fraud Auditing and Forensic Accounting: New Tools and Techniques (1995). Apabila salah satu dari empat elemen diatas, dapat diminimalisir, maka tingkat terjadinya kecurangan akan semakin rendah.

Abdullah Alhadza (2001) dalam Hartoto

(Budaya Cheating: Penyakit dalam Dunia Pendidikan)menjelaskan bahwa ada empat faktor yang menjadi penyebab cheating yaitu: (1) Faktor individual atau pribadi dari cheater, 2) faktor lingkungan atau pengaruh kelompok, (3) faktor sistem evaluasi dan (4) faktor guru/dosen atau penilai.

Namun, akibat seringnya kecurangan dilakukan secara langsung maupun tidak langsung oleh mahasiswa, kecurangan akademik (academic fraud) semakin ditoleransi dan dianggap hal biasa yang tidak perlu dihindari. Academic fraud biasanya dilakukan karena kurangnya percaya diri atas jawaban yang dimiliki, akhirnya lebih percaya jawaban orang lain. Alasan lain karena mahasiswa malas belajar dan lebih senang mencari jawaban di buku atau alat lain selama ujian berlangsung. Tujuannya adalah untuk mendapatkan nilai yang baik. Bagi akademisi, kecurangan akademik (academic fraud) dilakukan dengan tujuan mendapatkan gelar lebih atau kredit lebih dari hasil penelitian atau tulias yang diperoleh dengan plagiarisme. Malahan, untuk beberapa kasus tertentu, Academic fraud ini dilakukan secara massal antara siswa dan guru hanya karena demi nama baik sekolah/kampus.

Matindas menyebutkan beberapa hal yang mendorong terjadinya kecurangan akademik:

1. Yang bersangkutan tidak tahu bahwa perbuatan itu tidak boleh dilakukan

2. Yang bersangkutan tahu hal itu tidak boleh dilakukan tetapi yakin bahwa ia dapat melakukannya tanpa ketahuan

3. Yang bersangkutan tahu hal itu tidak boleh dilakukan dan tidak yakin bahwa perbuatannya tidak akan diketahui, tetapi ia tidak melihat kemungkinan lain untuk mencapai tujuan utamanya (lulus atau mendapat nilai kredit untuk kenaikan pangkat), dan berharap agar perbuatannya tidak ketahuan. Dalam beberapa hal ia mungkin percaya bahwa walaupun temannya mungkin mengetahui kecurangannya, tetapi teman itu tidak akan melaporkan kepada pihak yang akan memberikan sanksi

4. Yang bersangkutan tidak percaya bahwa ancaman sanksi akan benar-benar dilakukan.

5. Yang bersangkutan tidak merasa malu apabila perbuatannya diketahui orang lain.

Lilis Ummi Faiezahmengemukan beberapa alasan mengapa kecurangan akademik kerap terjadi, yaitu:

1. Tuntutan orang tua dan masyarakat yang berlebihan terhadap prestasi.

2. Kurangnya pengetahuan tentang pembuatan suatu karya tulis.

3. Kurangnya budaya membaca.

Penelitian ini terfokus pada kecurangan akademik yang dilakukan oleh mahasiswa serta saran pencegahannya di Universitas Muhammadiyah Sukabumi. ini adalah:

Adapun tujuan umum dari kegiatan penelitian

1. Mengukur besarnya pengaruh Greed terhadap academic fraud.

2. Mengukur besarnya pengaruh Opportunity terhadap academic fraud.

3. Mengukur besarnya pengaruh Need terhadap academic fraud.

4. Mengukur besarnya pengaruh Exposure terhadap academic fraud.

Penelitian ini diarahkan untuk memberikan manfaat sebagai berikut:

1. Untuk Memperoleh pemahaman tentang besarnya pengaruh Greed terhadap academic fraud.

2. Untuk Memperoleh pemahaman tentang besarnya pengaruh Opportunity terhadap academic fraud.

3. Untuk Memperoleh pemahaman tentang besarnya pengaruh Need terhadap academic fraud.

Untuk Memperoleh pemahaman tentang besarnya pengaruh Exposure terhadap academic fraud.

\section{Kajian Pustaka dan Pengembangan Hipotesis $\square$}

Von Dran, Callahan, dan Taylor (Lambert, Hogan dan Barton, 2003) mendefinisikan kecurangan 
akademik sebagai intensitas perilaku yang tidak beretika. Kecurangan akademik juga dapat diartikan sebagai perilaku yang dilakukan oleh pelajar dengan sengaja, meliputi beberapa bentuk perilaku seperti pelanggaran terhadap aturan dalam penyelesaian tugas dan ujian, memberikan keuntungan kepada pelajar lain dalam mengerjakan tugas atau ujian dengan cara yang tidak jujur, dan pengurangan keakuratan yang diharapkan pada performansi pelajar (Cizek dalam Riski 2009). Hendricks (Riski, 2009) mendefinisikan kecurangan akademik sebagai bentuk perilaku yang mendatangkan keuntungan bagi pelajar secara tidak jujur termasuk di dalamnya menyontek, plagiarisme, mencuri dan memalsukan sesuatu yang berhubungan dengan akademik.

Hendricks (Riski, 2004) menambahkan bahwa kecurangan akademik disebabkan oleh beberapa faktor, antara lain:

\section{Individual}

Terdapat berbagai faktor yang dapat mengidentifikasikan karakteristik individu yang dapat digunakan untuk memprediksi perilaku curang. Variabel-variabel tersebut, antara lain:

a. Usia, pelajar yang lebih muda lebih banyak melakukan kecurangan daripada pelajar yang lebih tua.

b. Jenis kelamin, siswa lebih banyak melakukan kecurangan daripada siswi. Penjelasan utama dari pernyataan tersebut dapat dijelaskan oleh teori sosialisasi peran jenis gender yakni wanita dalam bersosialisasi lebih mematuhi aturan daripada laki-laki.

c. Prestasi akademik, hubungan prestasi akademik dengan kecurangan akademik bersifat konsisten. Pelajar yang memiliki prestasi belajar rendah lebih banyak melakukan kecurangan akademik daripada pelajar yang memiliki prestasi belajar tinggi. Pelajar yang memiliki prestasi belajar rendah berusaha mencapai prestasi akademik yang lebih tinggi dengan cara berperilaku curang.

d. Pendidikan orang tua, pelajar yang mempunyai orang tua dengan latar pendidikan yang tinggi akan lebih mempersiapkan diri dalam mengerjakan tugas dan ujian.

e. Aktivitas ekstrakurikuler, pelajar yang banyak terlibat dalam kegiatan ekstrakurikuler dilaporkan lebih banyak melakukan kecurangan akademik.

2. Kepribadian

a. Moralitas, pelajar yang memiliki level kejujuran yang rendah akan lebih sering melakukan perilaku curang, namun penelitian yang dilakukan untuk mengetahui hubungan antara perkembangan moral dengan menggunakan tahapan moral Kohlberg menunjukkan hanya ada sedikit hubungan diantara keduanya.

b. Variabel yang berkaitan dengan pencapaian akademik, variabel yang berkaitan dengan kecurangan akademik adalah motivasi, pola kepribadian dan pengharapan terhadap kesuksesan. Motivasi berprestasi memiliki hubungan yang positif dengan perilaku curang.

c. Impulsifitas, afektivitas dan variabel kepribadian yang lain, terdapat hubungan antara perilaku curang dengan impulsifitas dan kekuatan ego. Selain hal tersebut, pelajar yang memiliki level tinggi dari tes kecemasan lebih cenderung melakukan perilaku curang.

3. Faktor kontekstual

a. Keanggotaan perkumpulan

Perlajar yang tergabung dalam suatu perkumpulan pelajar akan lebih sering melakukan perilaku curang. Pada perkumpulan pelajar diajarkan norma, nilai dan kemampuan-kemampuan yang berhubungan dengan mudahnya perpindahan perilaku curang. Pada suatu perkumpulan, penyediaan catatan ujian yang lama, tugas-tugas, tugas laboratorium dan tugas akademik lain mudah untuk dicari dan didapatkan.

b. Perilaku teman sebaya

Perilaku teman sebaya memiliki pengaruh yang penting terhadap kecurangan akademik. Hubungan tersebut dijelaskan dengan menggunakan teori pembelajaran sosial dari Bandura dan teori hubungan perbedaan dari Edwin Sutherland. Teori-teori tersebut mengemukakan bahwa perilaku manusia dipelajari dengan mencontoh perilaku individu lain yang memiliki perilaku menyimpang akan berpengaruh terhadap peningkatan perilaku individu yang menirunya.

c. Penolakan teman sebaya terhadap perlaku curang

Penolakan teman sebaya terhadap perilaku curang merupakan salah satu faktor penentu yang penting dan dapat berpengaruh terhadap perubahan perilaku curang pada pelajar.

4. Faktor situasional

a. Belajar terlalu banyak, kompetisi dan ukuran kelas 
Pelajar yang belajar terlalu banyak dan menganggap dirinya berkompetisi dengan pelajar lain lebih cenderung melakukan kecurangan dibandingkan pelajar yang tidak belajar terlalu banyak. Ukuran kelas juga menentukan kecenderungan perilaku curang pelajar dimana pelajar akan lebih berperilaku curang jika berada di dalam ruangan kelas yang besar.

b. Lingkungan ujian

Pelajar lebih cenderung melakukan kecurangan di dalam ujian jika pelajar tersebut berpikir bahwa hanya ada sedikit resiko ketahuan ketika melakukan kecurangan.

Tiap faktor yang disebut di atas sesungguhnya adalah faktor yang mungkin terkait satu dengan lainnya. Sebagai contoh, self-esteem (harga diri) boleh jadi berkaitan dengan kompetensi akademik dan komptensi akademik juga berkaitan dengan selfefficacy maupun teknik belajar.

Colby (2006) menyatakan bahwa di Arizuna State University kategori kecurangan akademik dibagi menjadi lima kategori seperti yang dipublikasikan oleh Arizuna State University Integrity Advocates. Kategori tersebut adalah:

\section{Plagiat}

a. Menggunakan kata-kata atau ide orang lain tanpa menyebut atau mencantumkan nama orang tersebut.

b. Tidak menggunakan tanda kutipan dan menyebut sumber ketika menggunakan kata-kata atau ide pada saat mengerjakan laporan, makalah dari bahan internet, majalah, koran, dll.

2. Pemalsuan data, misalnya membuat data ilmiah yang merupakan data fiktif.

3. Penggandaan tugas, yakni mengajukan dua karya tulis yang sama pada dua kelas yang berbeda tanpa izin dosen/guru.

4. Menyontek pada saat ujian

a. Menyalin lembar jawaban orang lain

b. Menggandakan lembar soal kemudian memberikannya kepada orang lain

c. Menggunakan teknologi untuk mencuri soal ujian kemudian diberikan kepada orang lain atau seseorang meminta orang lain mencuri soal ujian kemudian diberikan kepada orang tersebut.

5. Kerjasama yang salah

a. Bekerja dengan orang lain untuk menyelesaikan tugas individual b. Tidak melakukan tugasnya ketika bekerja dengan sebuah tim.

Abdullah Alhadza (2001) menjelaskan bahwa agar pelajar selalu tidak melakukan kecurangan akademik pada saat ujian maka caranya adalah mengkondisikan keempat faktor yang menyebabkan pelajar berperilaku curang di atas ke arah yang mendukung, yaitu sebagai berikut:

1. Faktor pribadi

a. Bangkitkan rasa percaya diri

b. Arahkan self consept pelajar ke arah yang lebih proporsional

c. Biasakan pelajar berpikir lebih realistis dan tidak ambisius

d. Tumbuhkan kesadaran hati nurani (Das Uber Ich) yang mampu mengontrol keinginan untuk berperilaku tidak etis.

2. Faktor Lingkungan dan Kelompok. Ciptakan kesadaran disiplin dan kode etik kelompok yang sarat dengan pertimbangan moral.

3. Faktor Sistem Evaluasi

a. Buat instrumen evaluasi yang valid dan reliable (yang tepat dan tetap)

b. Terapkan cara pemberian skor yang benarbenar objektif

c. Lakukan pengawasan yang ketat

d. Bentuk soal disesuaikan dengan perkembangan kematangan peserta didik dan dengan mempertimbangkan prinsip paedagogy serta prinsip andragogy.

4. Faktor Guru/Pengajar

a. Berlaku objektif dan terbuka dalam pemberian nilai.

b. Bersikap rasional dan tidak melakukan kecurangan dalam memberikan tugas ujian.

c. Tunjukkan keteladanan dalam perilaku moral.

d. Berikan umpan balik atas setiap penugasan.

Colby (2006) menyebutkan beberapa cara yang bisa dilakukan oleh pelajar untuk menghindari kecurangan akademik, antara lain:

a. Bertanya, banyak pelajar yang menyontek dengan alasan tidak memahami cara mengerjakan soal ujian, oleh karenanya sangat penting untuk bertanya kepada pengajar pada saat proses belajar mengajar.

b. Seek tutoring, meminta kepada guru atau dosen untuk mencarikan seseorang yang bisa membantu proses belajar, seperti guru privat. 
c. Jaga kesehatan, kesehatan sangat penting untuk mendukung proses belajar dan juga pada saat ujian oleh karenanya seorang pelajar harus mampu menjaga kesehatan, baik kesehatan fisik maupun kesehatan psikis.

Jack Bologne berpendapat bahwa akar penyebab korupsi ada empat, yaitu:

Greed, Opportunity, Need dan Exposure (GONE). Greed, terkait keserakahan dan kerakusan para pelaku. Opportuniy terjadi karena sistem yang memberi peluang untuk melakukan kecurangan. Need, sikap mental yang tidak pernah merasa cukup, selalu sarat dengan kebutuhan yang tidak pernah usai. Exposure, hukuman yang dijatuhkan kepada para pelaku korupsi yang tidak memberi efek jera pelaku maupun orang lain.

Dari uraian diatas, hipotesis yang diajukan adalah sebagai berikut:

$\mathrm{H} 1=$ Greed Berpengaruh terhadap terjadinya academic fraud.

$\mathrm{H} 2$ = Opportunity Berpengaruh terhadap terjadinya academic fraud.

H3 = Need Berpengaruh terhadap terjadinya academic fraud.

$\mathrm{H} 4$ = Eksposure Berpengaruh terhadap terjadinya academic fraud.

\section{Metode Penelitian}

Metode penelitian yang digunakan dalam penelitian ini adalah metode deskriptif asosiatif dengan menggunakan pendekatan studi kasus dilihat dari permasalahan yang ada di masyarakat. Pengertian desriptif menurut Ety et al (2007:18) menyatakan sebagai berikut: "metode penelitian deskriptif merupakan penelitian yang dilakukan untuk mengetahui nilai variabel mandiri, baik satu variabel maupun lebih tanpa membuat perbandingan atau menghubungkanya dengan variabel lain".

Metode asosiatif merupakan metode yang digunakan untuk mencari hubungan dua variabel atau lebih. Dengan metode ini penulis bermaksud mengumpulkan data dan meneliti aspek-aspek yang berkaitan dengan masalah yang akan diteliti. Penelitian yang dilakukan termasuk kedalam penelitian kuantitatif. Data yang digunakan dalam penelitian ini menggunakan data sekunder yang berasal dari laporan pendapatan daerah yang kemudian diproses dan

Riset Akuntansi dan Keuangan Indonesia, 1(2), 2016 dianalisis sehingga diperoleh hasil mengenai objek dan dapat ditarik kesimpulan.

Penelitian ini akan dilaksanakan di Universitas Muhammadiyah Sukabumi. Subjek penelitian ini dilakukan kepada seluruh mahasiswa Universitas Muhammadiyah Sukabumi. Data-data dalam penelitian ini terdiri atas data-data primer berupa daftar pertanyaan (kuesioner) yang diberikan kepada responden.

Dalam mengumpulkan data, peneliti menggunakan teknik pengumpulan data berupa:

1. Teknik Dokumentasi, yaitu pengumpulan data dan informasi dengan cara memanfaatkan sejumlah dokumen dan bahan-bahan tertulis yang memuat data yang berhubungan dengan penelitian ini.

2. Kuisioner, yaitu teknik pengumpulan data dengan memberikan daftar pertanyaan kepada responden, dimana kuisioner ini disusun dengan alat tertutup, dalam artian setiap pertanyaan disediakan alternative jawaban, sehingga responden cukup memilih alternative jawaban yang ada.

3. Wawancara, yaitu mengadakan Tanya jawab secara langsung dengan pihak-pihak berkompeten dan mempunyai kaitan erat dengan objek penelitian guna memperoleh informasi yang selengkap-lengkapnya.

\section{Analisis Data}

Metode analisis yang digunakan dengan menguji validitas variabel laten. Untuk menguji validitas variabel laten digunakan prosedur yang dibuat oleh Churchill, Gerbing dan Anderson, dimana validitas sebuah variabel laten diperiksa dengan menggunakan analisa faktor atas nilai dari beberapa indikator penelitian yang telah ditetapkan dan dianggap dapat mengukur sebuah variabel laten dalam sebuah penelitian. Dalam penelitian ini digunakan analisis faktor konfirmatori atau confirmatory factor analysis (CFA). CFA merupakan pengembangan dari analisa faktor yang dikembangkan oleh Joreskog (1967) dan Joreskog dan Lawley (1971) yang menggunakan pendekatan atas dasar maksimum likelihood (ML). Dengan pendekatan ini, para peneliti dapat menguji hipotesis bahwa ada sejumlah faktor yang dapat menggambarkan interkorelasi antar variabel. Dengan konsep meminimumkan fungsi maksimum likelihood ini maka akan didapatkan likelihood ratio chi-square test untuk menguji menguji hipotesis bahwa model yang dihipotesiskan cocok atau 
sesuai (fit) dengan data. (Imam Ghozali, 2013). Evaluasi validitas ini menggunakan factor loading untuk menentukan apakah sebuah variabel indikator memang dapat dikelompokkan menjadi satu, sah dan memiliki common variance. Stevens (1992) menyarankan untuk menggunakan cut-off dari factor loading sebesar 0.36, sedangkan Ridgon dan Ferguson (1991) menyarankan agar cut-off dari factor loading sebesar 0.70 dengan nilai t lebih besar sama dengan 2.00. Untuk uji realibilitas variabel laten diuji dengan menggunakan dua ukuran, yaitu dengan menggunakan construct reliability (CR) dan variance extracted (VE). Nilai batas yang dipergunakan untuk menilai sebuah tingat reliabilitas yang dapat dipergunakan dapat diterima jika memiliki CR > 0.7 sedangkan untuk nilai VE yang direkomendasikan paling sedikit 0.50 . Pengujian hipotesis dalam penelitian ini menggunakan metode Partial Least Square (PLS).PLS merupakan metode alternatif analisis dengan Structural Equation Modelling (SEM) yang berbasis variance.Keunggulan metode ini adalah tidak memerlukan asumsi dan dapat diestimasi dengan jumlah sampel yang relatif kecil. Alat bantu yang digunakan berupa program SmartPLS Versi 3 yang dirancang khusus untuk mengestimasi persamaan struktural dengan basis variance.

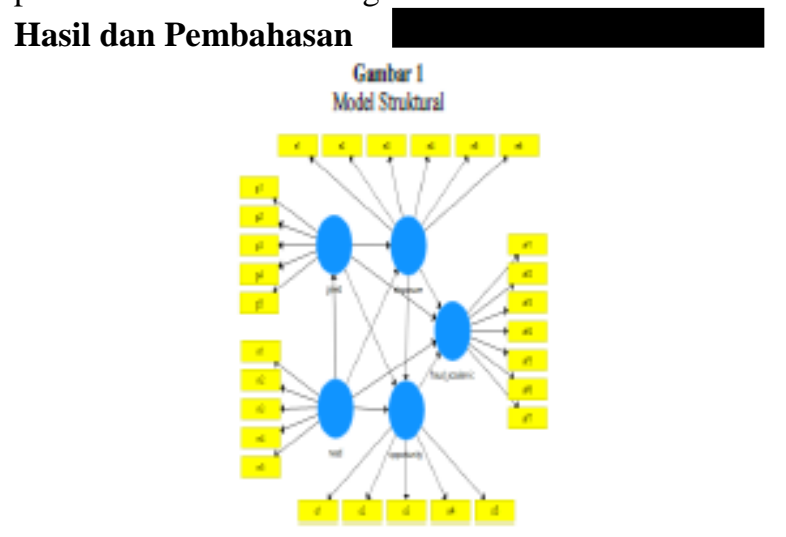

Gambar diatas menunjukkan bahwa konstruk fraud academic (fa) diukur dengan 7 buah indikator yaitu af1, af2, af3, af4, af5, af6 dan af7.Demikian juga konstruk eksposure (e) diukur dengan 6 indikator yaitu e1, e2, e3, e4, e5 dan e6. Konstruk greed (g) diukur dengan 5 indikator yaitu g1, g2, g3, g4, dan g5 sedangkan kontruk need (n) diukur dengan 5 indikator yaitu n1, n2, n3,m n4, dan n5 serta konstruk opportunity (o) diukur dengan menggunakan 5 indikator yaitu o1, o2, o3, o4, dan o5. Hubungan yang akanditeliti (hipotesis) dilambangkan dengan anak panah antara konstruk.

\section{Uji Validitas}

Suatu indikator dinyatakan valid jika mempunyai loading factor di atas 0,6 terhadap konstruk yang dituju. Output SmartPLS untuk loading factor memberikan hasil sebagai berikut:

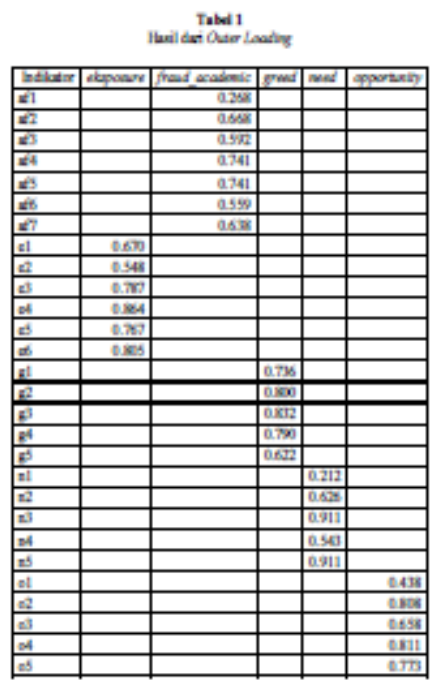

Pengujian validitas untuk indikator reflektif menggunakan korelasi antara skor item dengan skor konstruknya. Pengukuran dengan indikator reflektif menunjukkan adanya perubahan pada suatu indikator dalam suatu konstruk jika indikator lain pada konstruk yang sama berubah (atau dikeluarkan dari model). Indikator reflektif cocok digunakan untuk mengukur persepsi sehingga penelitian ini menggunakan indikator reflektif. Tabel di atas menunjukkan bahwa loading factor memberikan nilai di atas nilai yang disarankan yaitu sebesar 0,6 sehingga dari tabel diatas terdapat beberapa indikator yang harus dibuang (dihapus). Indikator yang valid akan dipergunakan dalam penelitian ini karena telah memenuhi convergent validity. Berikut adalah diagram loading factor masing-masing indikator dalam model penelitian: 


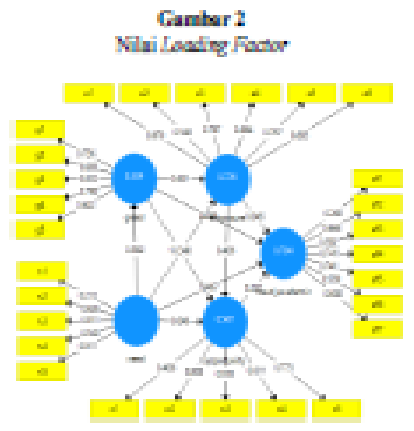

Lebih lanjut, indikator reflektif juga perlu diuji discriminant validity dengan melihat nilai square root of average variance extracted (AVE). Nilai yang disarankan adalah di atas 0,5. Berikut adalah nilai AVE dalam penelitian ini:

\section{Uji Reliabilitas}

Uji reliabilitas dilakukan dengan melihat nilai composite reliability dari blok indikator yang mengukur konstruk. Hasil composite reliability akan menunjukkan nilai yang memuaskan jika di atas 0,7. Uji reliabilitas juga bisa diperkuat dengan Cronbach ${ }^{\text {ee }} \mathrm{s}$ Alpha di mana output SmartPLS Versi 3 memberikan hasil sebagai berikut :

Tabel 2

Anerge Voriana fintuatid (ave.

\begin{tabular}{|c|c|}
\hline & $\begin{array}{l}\text { Anerage Varboue Fimartad } \\
\text { (AVE) }\end{array}$ \\
\hline dipeare & 0.559 \\
\hline fiand anodrels & 0.354 \\
\hline gead & $0.5 \pi$ \\
\hline end & $0.4 \pi$ \\
\hline gegarsedy & $0.5 \mathrm{D}$ \\
\hline
\end{tabular}

Tabel di atas menunjukkan bahwa nilai composite reliability untuk semua konstruk adalah di atas 0,7 yang menunjukkan bahwa semua konstruk pada model yang diestimasi memenuhi kriteria discriminant validity. Nilai composite reliability yang terendah adalah sebesar 0.797 dengan nilai Cronbach's Alpha sebesar 0.674 .

\section{Pengujian Model Struktural (Inner Model)}

Setelah model yang diestimasi memenuhi kriteria Outer Model, berikutnya dilakukan pengujian model structural (Inner Model). Berikut adalah nilai R-Square pada konstruk:

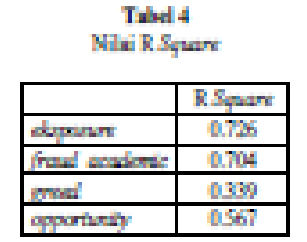

Tabel di atas memberikan nilai 0.726 untuk konstruk eksposure yang berarti bahwa eksposure mampuh menjelaskan varian fraud sebesar 72.6\%.setalah dilakukan pengujian model struktural (inner model), maka selanjutnya dilakukan uji hipotesis untuk melihat besarnya pengaruh antar konstruk.

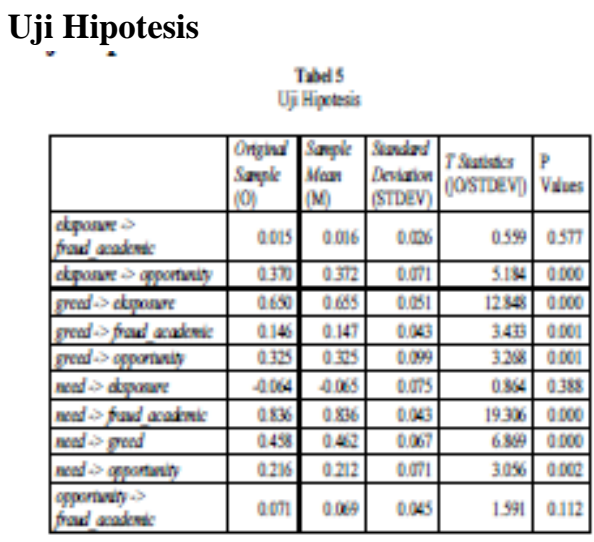

Tabel di atas menunjukkan bahwa hubungan antara greed dengan academic fraud adalah signifikan dengan t-statistik sebesar 3,433 (lebih besar dari nilai 1,972 (t table dengan tingkat prob 5\% dan df 198)). Nilai original sample estimate adalah positif yaitu sebesar

0,146 yang menunjukkan bahwa arah hubungan antara greed dengan academic fraud adalah positif. Dengan demikian hipotesis $\mathrm{H} 1$ dalam penelitian ini yang menyatakan bahwa 'greed berpengaruh terhadap academic fraud' diterima.

Tabel di atas menunjukkan bahwa hubungan antara opportunity dengan academic fraud adalah signifikan dengan tstatistik sebesar 1,561 (lebih kecil dari nilai 1,972 ( $\mathrm{t}$ table dengan tingkat prob 5\% dan df 198)). Nilai original sample estimate adalah positif yaitu sebesar 0,071 yang menunjukkan bahwa arah hubungan antara opportunity dengan academic fraud adalah positif. Dengan demikian hipotesis $\mathrm{H} 2$ dalam penelitian ini yang menyatakan bahwa 'opportunity berpengaruh terhadap academic fraud' ditolak.

Tabel di atas menunjukkan bahwa hubungan antara need dengan academic fraud adalah signifikan 
dengan t-statistik sebesar 19,306 (lebih besar dari nilai 1,972 (t table dengan tingkat prob 5\% dan df 198)). Nilai original sample estimate adalah positif yaitu sebesar 0,836 yang menunjukkan bahwa arah hubungan antara need dengan academic fraud adalah positif. Dengan demikian hipotesis H3 dalam penelitian ini yang menyatakan bahwa 'need berpengaruh terhadap academic fraud' diterima.

Tabel di atas menunjukkan bahwa hubungan antara eksposure dengan academic fraud adalah signifikan dengan t-statistik sebesar 0,559 (lebih kecil dari nilai 1,972 (t table dengan tingkat prob 5\% dan df 198)).

Nilai original sample estimate adalah positif yaitu sebesar 0,015 yang menunjukkan bahwa arah hubungan antara eksposure dengan academic fraud adalah positif. Dengan demikian hipotesis H4 dalam penelitian ini yang menyatakan bahwa eksposure berpengaruh terhadap academic fraud ${ }^{\text {ee }}$ ditolak. Berikut adalah diagram nilai t-statistic berdasarkan output dengan SmartPLS Versi 3:

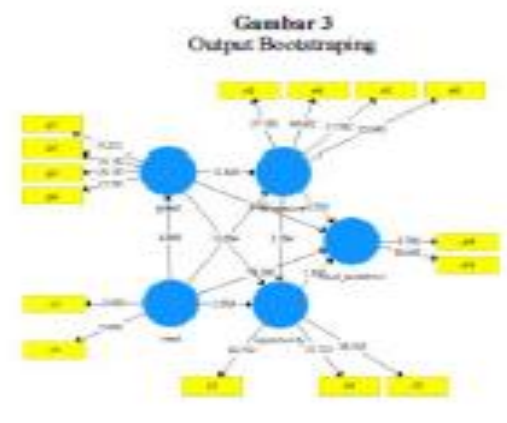

\section{Pembahasan}

1. Hipotesis pertama yang diajukan dalam penelitian ini adalah hubungan antara greed dengan academic fraud, dimana dalam penelitian ini hipotesis pertama

2. diterima sehingga greed berperan penting dalam terjadinya academic fraud di kalangan mahasiswa. Faktor greed merupakan faktor yang berhubungan langsung dengan perilaku setiap individu. Faktor ini terjadi karena rasa ketidakpuasan seorang mahasiswa akan sesuatu yang telah diperolehnya sehingga faktor greed ini dijadikan suatu kebiasaan yang harus dilakukan untuk bisa mendapatkan nilai yang sempurna.

3. Hipotesis kedua yang diajukan dalam penelitian ini adalah hubungan antara opportunity dengan academic fraud, dimana dalam penelitian ini hipotesis kedua ditolak sehingga opportunity tidak berperan penting dalam terjadinya academic fraud. Opportunity merupakan faktor yang berhubungan dengan lingkungan eskternal mahasiswa seperti adanya kesempatan yang seolah-olah diberikan sehingga opportunity dapat dikatakan berhubungan dengan sistem yang ada.

4. Hipotesis ketiga yang diajukan dalam penelitian ini adalah hubungan antara need dengan academic fraud, dimana dalam penelitian ini hipotesis ketiga diterima sehingga need mempunyai peranan atas terjadinya academic fraud. Need merupakan faktor yang berasal dari diri sendiri. Need biasanya terjadi apabila adanya suatu desakan yang mengharuskan seorang mahasiswa mendapatkan nilai sempurna. Desakan ini dapat berasal dari lingkungan keluarga ataupun dari lingkungan kampus.

5. Hipotesis keempat yang diajukan dalam penelitian ini adalah hubungan antara eksposure dengan academic fraud, dimana dalam penelitian ini hipotesis

6. keempat ditolak sehingga eksposure tidak mempunyai peranan penting dalam terjadinya academic fraud. Ekposure dalam academic fraud merupakan faktor

7. yang berhubungan dengan proses pembelajaran berbuat curang, karena manganggap sanksi yang diberikan terlalu ringan.

\section{Simpulan}

Berdasarkan hasil penelitian, dapat disimpulkan bahwa dari empat hipotesis yang diajukan terdapat dua hipotesis yang diterima dan dua lainnya ditolak. Greed dan Need yang merupakan faktor internal yang terdapat didalam diri seseorang merupakan faktor penyebab terjadinya academic fraud sedangkan faktor opportunity dan eksposure yang merupakan faktor luar tidak mempunyai peranan dalam terjadinya academic fraud. Faktor greed dan need merupakan faktor yang berhubungan dengan individu pelaku fraud, atau sering disebut sebagai faktor individual. Keserakahan dan kebutuhan merupakan hal yang bersifat sangat personal sehingga sulit sekali untuk dihilangkan oleh ketentuan perundangan, karena jika sudah butuh ditambah motivasi dan sikap serakah maka orang akan cenderung melanggar ketentuan. 


\section{Daftar Pustaka}

[1] Colby, B. (2006). Cheating; What is it (Online), (http://clas.asu.edu/files/AI\%20Flier.pdf, diakses 18 Mei 2010).

[2] Ghozali, Imam. Model Persamaan Struktural Konsep dan Aplikasi dengan Program Amos 21.0. Semarang : Badan Penerbit Universitas Diponegoro, 2013.

[3] Hartoto. Budaya Cheating: Penyakit dalam Dunia Pendidikan.

[4] http://budimatindas.blogspot.co.id/2010/08/mence gah-kecurangan-akademik.html, diakses tanggal 08 Januari 2016

[5] http://kisuta.com/2014-12-05/mencontek-cikalbakal-plagiarisme-dan-korupsi, diakses tanggal 08 Januari 2016

[6] http://www.republika.co.id/berita/pendidikan/berit a-pendidikan/11/06/07/lmeuui-satusekolah-mencontek-massal-saat-ujian-kepalasekolah-dan-guru-diberhentikan, diakses tanggal 08 Januari 2016

[7] http://www.kompasiana.com/elis.nvs/korupsikecil-itu-bernama menyontek_552e2e726ea834 9d178b45ac , diakses tanggal 08 Januari 2016

[8] http://news.detik.com/internasional/2159488/skan dalmencontek-massal-60-mahasiswa-harvardkena-skorsing, diakses tanggal 08 Januari 2016

[9] http://news.de.tikcom/internasional/2159488/skan dalmencontek-massal-60-mahasiswa-harvardkena-skorsing diakses tanggal 08 Januari 2016

[10] http://www.konsultanstatistik.com/2010/10/simula si-smartpls_852.html diakses tanggal 10 Januari 2016

[11]Lambert, E.G., Hogan, N.L., \& Barton, S.M. (2003). Collegiate academic dishonesty revisited: what have they done, how often have they done it, who does it, and why did they do it. Electronic Journal of Sosiology.

[12] Muslimah. Persepsi Mahasiswa Akuntansi Terhadap Praktik-Praktik Kecurangan Akademik (Academic Fraud)

[13] Miranda, Sandra Marisa. Academic Dishonesty Understanding How Undergraduate Students Think and Act. ISATT 2011 Conference. University of Minho. Portugal. 2011

[14] Sierra, J.J. dan M. R. Hyman. 2008. Ethical Antecendents of Cheating Intentions: Evidence of
Mediation. Journal Academic Ethics, 6. Hal 5166.

[15] Sudarmo, Sawardi. Buku Panduan Fraud Auditing Ed.5. Jakarta: Pusat Pendidikan dan Pelatihan Pengawasan BPKP, 2008.

[16] Tuanakotta, Theodorus M. Akuntansi Forensik dan Audit Investigatif Edisi 2. Jakarta : Penerbit Salemba Empat, 2012.

[17] Transparancy Internatoinal, Corruption Perceptions Index 2014. 